有限幅平板上の乱流強制対流熱伝達*

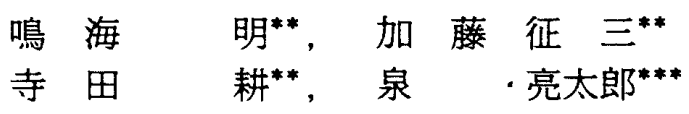

\title{
Forced Heat Convection in Turbulent Flow over a Flat Plate with Finite Width
}

\author{
by Akira NARUMI, Seizo KATO, \\ Ko TERADA and Ryotaro IZUMI
}

\begin{abstract}
Heat transfer characteristic in turbulent flow over a flat plate having finite width is experimentally studied with emphasis on the promotion of heat transfer caused by the edge effect due to the secondary flow at the plate corner. The measurements under the condition of uniform heat flux are performed for the geometries of finite widths $w=60 \sim 360 \mathrm{~mm}$ and of finite thicknesses $2 h=10 \sim 40$ $\mathrm{mm}$.

The relatively great promotion of heat transfer is always obtained at the side edge region of finite width and it depends mainly on plate thickness. The local heat transfer coefficient in the lateral direction is well expressed by the empirical formulae of Eqs. ( 3$) \sim(6)$ with plate thickness as a parameter. The formulae for the mean heat transfer coefficients are also established by the set of Eqs.
\end{abstract} ( 7$) \sim(10)$.

Key Words: Convective Heat Transfer, Turbulent Boundary Layer, Finite Width Plate, Heat Transfer Enhancement, Edge Effect, Secondary Flow

\section{1. 緒 言}

熱交換器などに使用されるく形伝熱面の板幅や板厚 が実用上有限であるため，とくに流れが乱流の場合， 有限幅側端付近には，曲管内の遠心力による二次流れ とは区別される，いわゆるプラントルの第 2 種の二次 流れが生じ(1) (4)，したがって伝熱特性も二次元平板 のそれとはかなり異なることが予想される。同種の現 象は流れに平行な突起物を伝熱促進要素としたフィン 付伝熱管にもみられる(5). しかし，伝熱促進機構はい まだ明確でなく，それに結びつく流動や伝熱の詳細な 特性を明らかにすることは工学上重要である．筆者ら は先に(6)，有限幅平板の流動特性を種々の幾可学的条 件下で調べ，側端付近で二次流れの発生を確認すると ともに、二次流れの強さとそれによる側端効果の影響 領域を定量的に明示し，これらによる伝熱促進効果を 示唆した。本研究は、この流動特性を基礎として, 平 板の乱流境界層に加熱面を設置して，板幅と板厚を 種々変化させた場合の有限幅平板上の強制乱流熱伝達 特性を測定し，二次流れによる側端効果の影響を実験

“昭和 58 年 11 月 21 日 第 922 回講演会において講演，原稿 受付 昭和 58 年 5 月 10 日，

** 正員，三重大学工学部（W514 津市上浜町 1515).

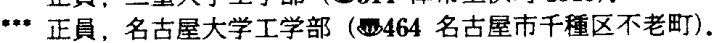

的に調べたもので，それによる伝熱促進効果を検討 し，定量的にもそれを評価しうる実験式の作成も試み た.

\section{2. 実験装置と方法}

本実験装置の概要を図 1 に示す．供試平板は前報(6) と同様に，前緑が半円形状で平板面に垂直な側端面を もつ全長約 $915 \mathrm{~mm}$ のベークライト製有限腷平板で あり，板幅 $w を 60 ， 90 ， 120$ および $360 \mathrm{~mm}$ （基準と なる無限幅平板）に，板厚 $2 h$ を $10 ， 15 ， 20 ， 30$ およ び $40 \mathrm{~mm}$ にそれそれ変化させた，加熱領域を流動実 験より前縁の影響がなくなり十分に発達した乱流境界 層が形成される前縁コーナからの距離 $x=110 \mathrm{~mm}$ か ら $x=715 \mathrm{~mm}$ の範囲にとり，平板支持部の影響をな くすため更に $200 \mathrm{~mm}$ の後端部を設けた. $30 \mu$ のステ ンンスはくを平板表裏の加熱領域にはり，直接通電し て等熱流束加熱とした。壁温は $x$ 方向に 13 箘所板幅 の $z$ 方向に4〜8 簓所に埋め込まれた $\phi 0.32$ の C $-\mathrm{C}$ 熱電対により測定した。熱損失測定のため板断面中央 部にも $x$ と $z$ 方向に各々 4 〜 箇所, 熱電対を設け た.この測定平板を $360 \mathrm{~mm} \times 360 \mathrm{~mm}$, 長さ $2300 \mathrm{~mm}$ の風洞測定部中央に垂直に設置したが，平板表亭の流 れの対称性が得られ，平板に沿う圧力こう配がないよ 
うに風洞測定部の流路幅を調整した。最大ブロッケー ジ比 $3.7 \%$ の $w=120 \mathrm{~mm}, 2 h=40 \mathrm{~mm}$ 平板でも表裏 の圧力差と压力こう配は压力係数にして各々0.008, 0.01 であった。 なお測定部入口においては $0.4 \%$ 以 内の速度の一様性があり，また主流の乱れ強さは本実 験範囲内の主流速度 $U_{\infty}=5 \sim 20 \mathrm{~m} / \mathrm{s}$ では $0.6 \%$ 以下 であった(7).

\section{3. 実呀結果と考察}

$3 \cdot 1$ 板側端の二次流れ 有限幅平板流れの特徵 的特性の一つは, 図 2 の等速度比線図に示すように側 端部にプラントルの第 2 種の二次流れ（図中矢印で示 す）が生じることである.（図中 $U, U$ 。はそれぞれ $x$ 方向速度，境界層外側の $x$ 方向速度を示す) 二次流れ の強さやその影響範囲は前報(6)によれば主に板厚に依 存する. 更に, 境界層厚さや乱れ強さの分布も等速度 比線図と同じ傾向を示しており，これらによる側端効 果が熱伝達を促進させる因子となり得るものと思われ る.

\section{$3 \cdot 2$ 壁面温度分布 上述の側端効果が熱伝達特}

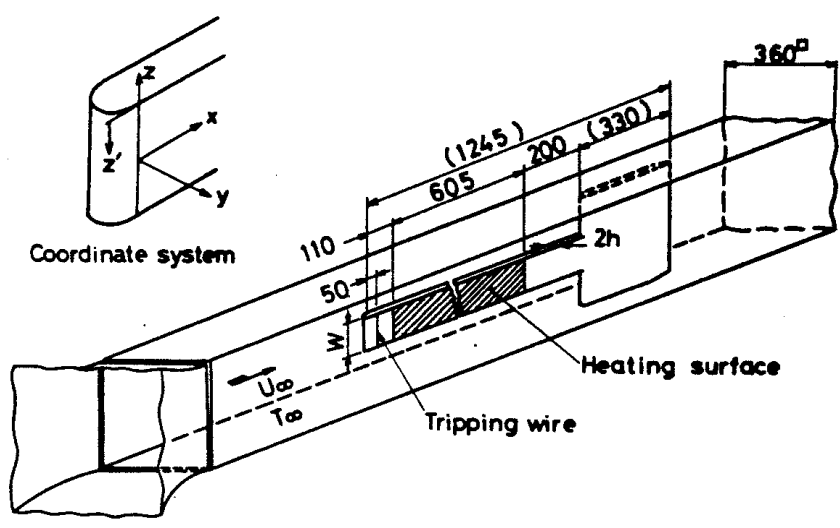

図 1 有限幅平板と実験装置概略図

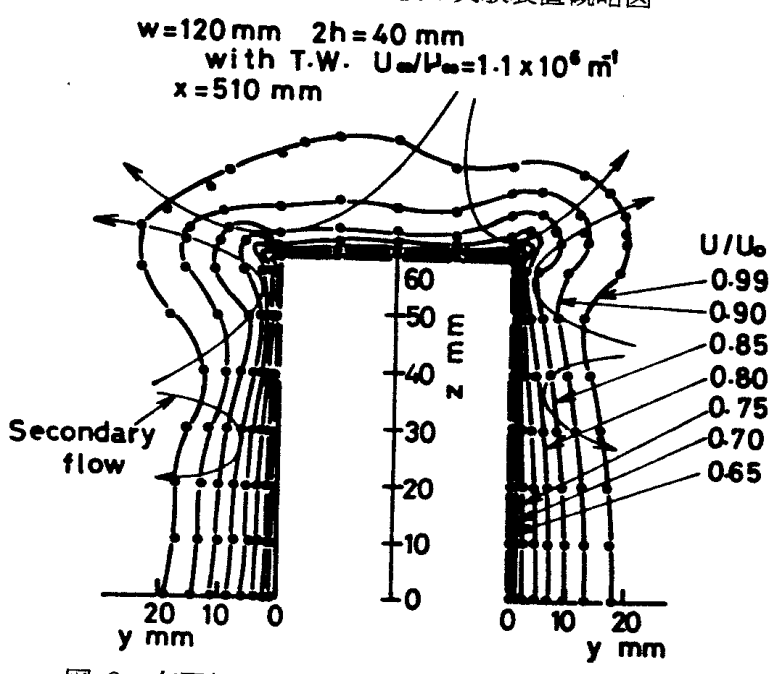

図 2 有限幅平板まわりの等速度比線図 $(y-z$ 断面)
性に及ほす影響をみるため，まず有限幅平板上の壁面 温度分布を、無限幅平板との比較のため無次元温度差 $\left(\Delta T_{w=\infty}-\Delta T\right) / \Delta T_{w=\infty}$ を用いて表したのが図 3 であ る.ここで, $\Delta T$ は壁温 $T(x, z)$ と主流温度 $T_{\infty}$ との 差, 添字 $w=\infty$ は無限幅平板, 横軸 $x_{h}$ は加熱面前縁 からの距離，また図中○印は熱電対埋込み位置を示 す、図から明らかなように等値曲線が $x_{h}$ 軸にほほ平 行になっていることより，有限幅平板の熱伝達に及浪 す影響は, 流れ方向 $x$ よりも板幅方向 $z$ に依存して いる.また，温度差も全領域で無限幅平板の場合より 小さく，側端に近づくほど著しい.すなわち， $w=120$ $\mathrm{mm}, 2 h=40 \mathrm{~mm}$ の平板側端では約 $60 \%$ も冷却され ており，側端効果により伝熱が促進されることを示し ている.

$3 \cdot 3$ 側端面からの熱損失 側端効果による伝熱 促進量を検討する前に，板側端面からの熱損失による 冷却割合を検討しておく必要がある，本実験の熱損失 としては，放射による熱量 $Q_{r}=\varepsilon \sigma A\left(T(x, z)^{4}-T_{\infty}^{4}\right)$ $(\varepsilon$ : 放射率 $=0.39, \sigma:$ ステファン・ボルツマン定数。 $A$ : 加熱面積)，加熱領域前・後端部と側端面方向への 熱損失 $Q_{l_{1}}$ と $Q_{l_{2}}$ があり，それらの値は加熱面の供 給熱量 $Q_{t}$ に対しそれぞれほほ $4 ， 0.2 ， 2 \%$ 以下と いずれもかなり小さい.しかし，Q $Q_{\iota_{2}}$ が側端部の壁温 に直接影響を及ほす恐れがあるので，測定壁温を境界 条件として, 平板内部の局所的温度分布を数值計算 し、側端部の熱損失による局所的板幅方向の位置 $z$ における平板内部への熱損失を算出した. その結果， $3 \cdot 6$ 節で後述する実験式作成の際用いる板幅中心 $z=$ $0 \mathrm{~mm}$ と板幅方向各 $z$ での熱伝達率の比において, 側 端部の熱損失を考慮した場合としない場合，その差は 高々 $5 \%$ 以下であった。この結果から 3.6 節の実験式 作成の際, 基準となる $w=120 \mathrm{~mm}$ 平板の板幅中心部 の熱伝達率の $10 \%$ 以上の増加分を有限幅平板の側端 効果による伝熱促進量とみなすことにした.

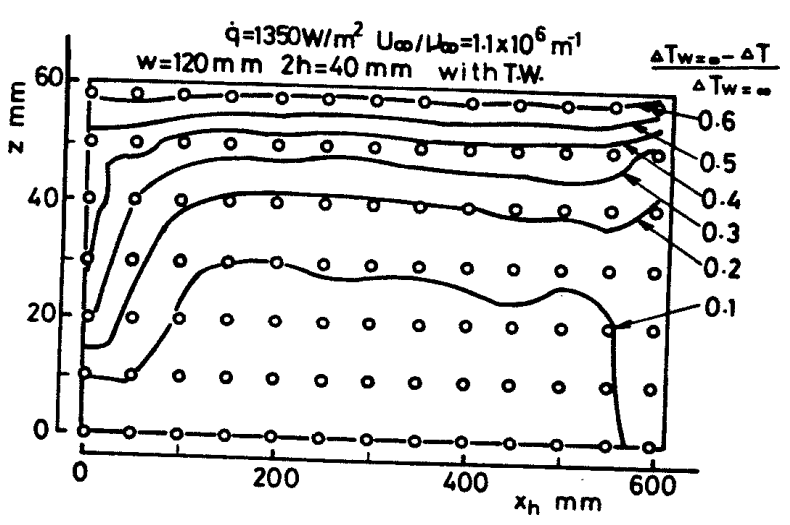

図 3 有限幅平板上の無次元温度分布 
$3 \cdot 4$ 熱伝達率本実験における局所熱伝達率を $h(x, z) \equiv\left\{\left(Q_{t}-Q_{r}\right) / A\right\} /\left\{T(x, z)-T_{\infty}\right\}$

と定義して，その無限偪平板に対する比として得られ た一例を図 4 に示す.この平板の場合 $z \leqq 30 \mathrm{~mm}$ では 無限幅平板とほほ同一で， $z \geqq 40 \mathrm{~mm}$ になると伝熱促 進が認められ始め， $z \geqq 50 \mathrm{~mm}$ の側端付近になると著 しく増加し $h_{w=\infty}$ の 50〜60\%増にもなり，功りの 伝熱促進量となることを示している. $h(x, z) /$ $h_{w=\infty}(x)$ は $x$ 方向に漸增する傾向があるが, $z$ 方向 への変化割合に比べれば無視しうるほど小さい.

次に，乱流促進化のためトリッピングワイヤ（T. W.と略記）を設置した場合の影響を調べてみた。ここ では $\phi 1$ の円柱を前縁コーナ部から $x=50 \mathrm{~mm}$ の位置 に設置した場合と設置しない場合を邓セルト数 $N_{u}(x, z)=h(x, z) x / \lambda$ とレイノルズ数 $R_{e_{x}}=U_{\infty} x /$ $\nu(\lambda$ : 熱伝導率, $\nu$ : 動粘性係数, 物性值は膜温度を 用いた）との関係を用いて比較したところ，図 5 に示 すように T.W.の有無による差異は現れなかった．前 縁が半円形状の本実験の場合，本実験範囲内では $x=$ $110 \mathrm{~mm}$ の加熱面開始点で T.W. を設置しなくてもす でに発達した乱流境界層が形成されれている神ためと思 われる。また図 5 には主流速度 $U_{\infty}$ と熱流束 $\dot{q}$ の影響 を調べた結果も併記してある， $U_{\infty}$ は $5 \sim 20 \mathrm{~m} / \mathrm{s} ， \dot{q}$ は $500 \sim 2000 \mathrm{w} / \mathrm{m}^{2}$ にわたって変化させたところ，い ずれも顕著な差異はなく，有限幅平板に対しても $N_{u}(x, z)$ を $R_{e x}$ の関数として用いればよいことを示 している.

図 6 に $w=120 \mathrm{~mm}, 2 h=20 \mathrm{~mm}$ の有限幅平板に対 する $N_{u}(x, z)$ と $R_{e x}$ との関係を示すが, $z \leqq 20 \mathrm{~mm}$ の测定点がほぼ重なっており，さらに板幅中心部では 無限幅平板の $N_{u w=\infty}$ とほほ一致し，しかも従来から の. 基準式 $N_{u x}=0.0296 R_{e x}{ }^{0.8} P_{r}^{1 / 3}{ }^{19}$ や $N_{u x}=$ $0.0296 R_{e x}{ }^{0.8} P_{r}{ }^{0.6(10)}$ ともほぼ一致することを考えれ

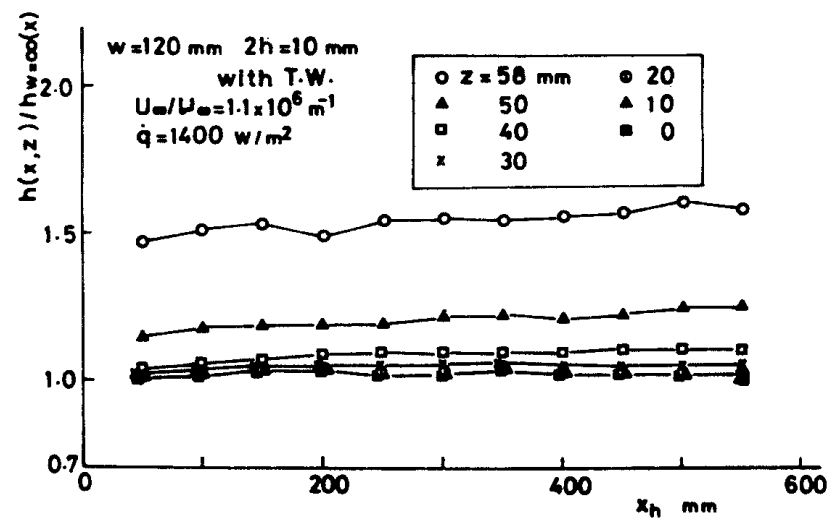

図 4 有限幅平板上の局所熱伝達率の変化
ば, $w=120 \mathrm{~mm}$ 平板の板幅中心 $z=0 \mathrm{~mm}$ では側端 効果の影響がほとんど及んでいないものと思われる。 側端効果による伝熱促進は本平板では $z>30 \mathrm{~mm}$

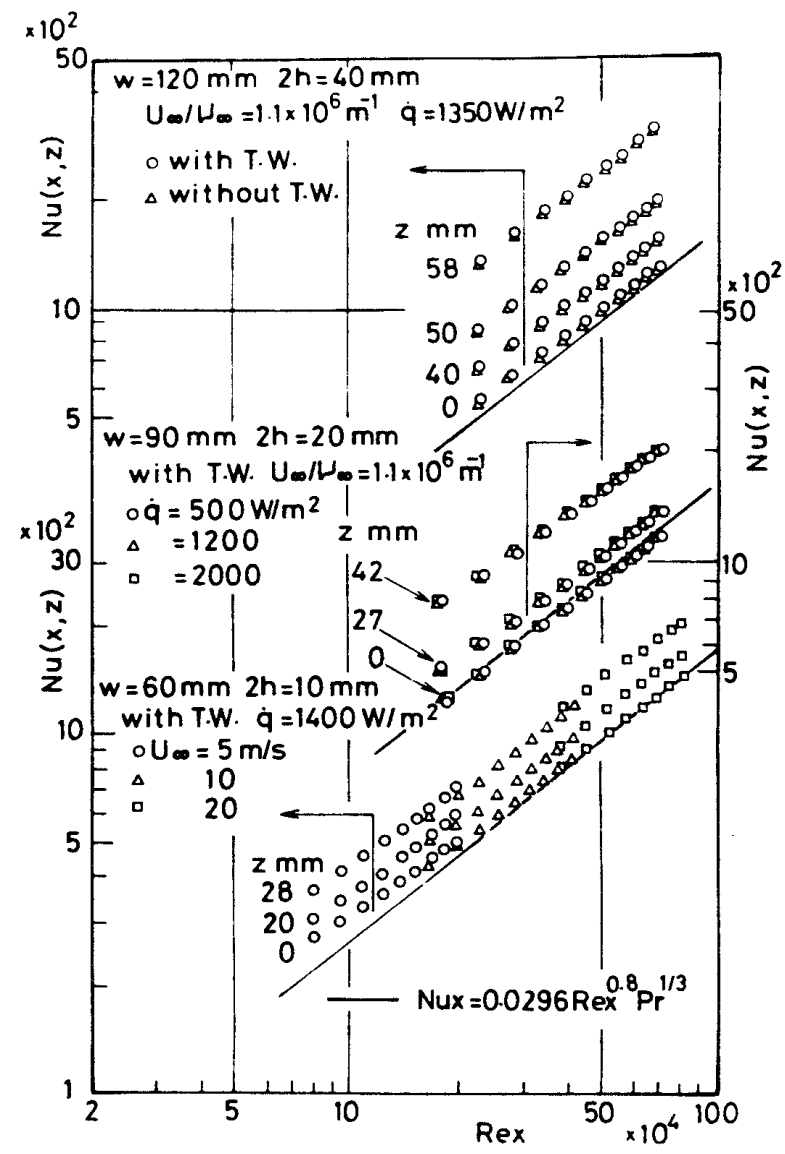

図 5 T.W.の有無， $\dot{q}, U_{\infty} の N_{u}(x, z)-R_{\boldsymbol{e x}} へ の$ 影響

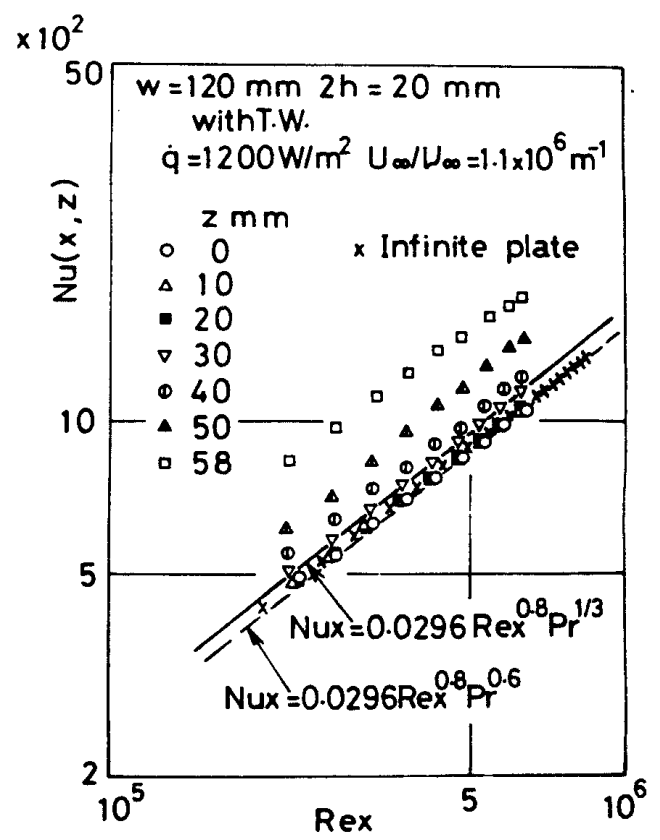

図 6 有限幅平板上の $N_{u}(x, z)$ と $R_{e x}$ の関係 
認められ始め，側端に近づくほど顥著に増加する。

$3 \cdot 5$ 板幅と板厚の影曛 有限幅側端効果による 熱伝達促進量を種々の幾何学的大きさに対しても比較 するため, 流れ方向距離 $x$ が陽に入ってこないス夕 ントン数によって検討する。この際 $h(x, z) / h_{w=\infty}(x)$ の $x$ 方向への変化が $z$ 方向に比し無視しうるほど小

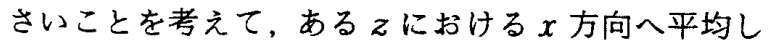
たスタントン数 $\overline{S_{t}(z)}$

$$
\overline{S_{t}(z)}=\left|\frac{1}{x_{h}} \int_{0}^{x_{h}} \frac{h(x, z)}{\rho c_{p} U_{\infty}} d x\right|_{z}
$$

（ $\rho$ : 密度, $c_{p}$ : 定圧比熱, 物性值は膜温度を用いた） を用いて検討する。これを無限幅平板の $\overline{S_{t w=\infty}}$ との比 として種々の幾何学的条件に対してプロットしたのが 図 7 である. 図には板幅 $w$ 一定で板厚 $2 h$ を, アスぺ クト比 A.R. $=w / 2 h=6$ 一定で $w$ と $2 h$ を, $2 h$ 一定 で $w$ をそれぞれ変化させた場合の結果が, 側端から の距離 $z^{\prime}=w / 2-z$ を横軸にとって記してある.いず れの幾何学的形状に対しても側端効果の強い領域 I と 板幅中心部のほとんど影響を受けない領域IIに明りょ うに区分され，しかも各領域に対し各々ほほ 1 本の直 線で表すことができる，領域 I では板厚が強い決定因 子であって，板厚が増すと直線のこう配が急になり， 同一板幅であれば熱伝達率はより向上し，その影響が より板幅中心部へ広がるようになる。

これらの結果は, 流動特性を調べた前報(6)の結果と よく対応しており，とくに本実験の伝熱促進領域と流 動実験による側端効果の領域とはほほ一致している。

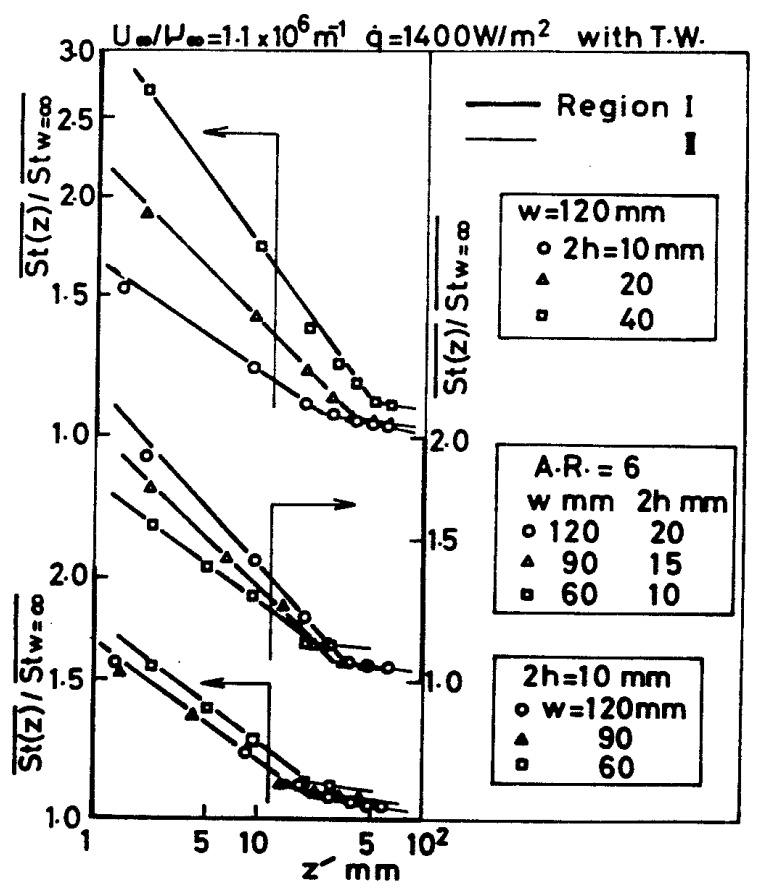

図 7 側端効果による伝熱促進への板幅，板厚の影響
3•6 板幅方向への熟伝達率の実験式 上述の結 果から $z=0 \mathrm{~mm}$ の板幅中心で側端効果をほとんど受 けない $w=120 \mathrm{~mm}$ 平板を評洒基準に選び、まず各 $w=120 \mathrm{~mm}$ 平板のすべての実験値について，板偪 中心 $z=0 \mathrm{~mm}$ における基準スタントン数 $\overline{S_{t 。}}$ に対す る各 $z$ の $\overline{S_{t}(z)}$ との比 $\overline{S_{t}(z)} / \overline{S_{t_{0}}}$ を算出して，この $\overline{S_{t}(z)} / \overline{S_{t_{0}}}$ を $z^{\prime}$ の関数として実験式を作成する. 次 に $w=120 \mathrm{~mm}$ 平板以外の他の有限幅平板に対して も同様な操作を行うが，これらの平板中心での $\overline{S_{t}(z)}$ が無限幅平板のそれより大きいので，各板厚に対して すでに求めた $w=120 \mathrm{~mm}$ 平板に関する実験式を用 いてこれらの平板中心 $z=0 \mathrm{~mm}$ での値を求め, この 值を各 $z$ におる值に乗ずるという修正を施して， 各 $z$ における $\overline{S_{t}(z)} / \overline{S_{t_{0}}}$ を求めた。このようにして 得られたすべての $\overline{S_{t}(z)} / \overline{S_{t_{0}}}$ から改めて各板厚に対 する統一的な実験式をそれぞれ作成した. $2 h=10 \mathrm{~mm}$ の場合を図 8 に示す.いずれの $w$ に対しても同一の直 線 I，IIによって整理できることがわかる，この整理 法を本実験で用いたすべての板厚に対して行った結果 は図 9 のようになり，実験式を

領域 I：

$$
\overline{S_{t}(z)} / \overline{S_{t_{0}}}=a_{1} z^{\prime}-b_{1}
$$

領域 II :

$$
\overline{S_{t}(z)} / \overline{S_{t_{0}}}=a_{\mathrm{n}} z^{\prime}-b_{\mathrm{n}}
$$

なる形でおけば各係数は図 10 で与えられる。すなわち

$$
\begin{aligned}
& a_{\mathrm{I}}=0.547(2 h)^{0.454}, \quad b_{\mathrm{l}}=0.037(2 h)^{0.556} \\
& a_{\mathrm{II}}=0.703(2 h)^{0.210}, \quad b_{\mathrm{II}}=0.007(2 h)^{0.753}
\end{aligned}
$$

ただし，適用範囲は $w \geqq 60 \mathrm{~mm}, 10 \mathrm{~mm} \leqq 2 h \leqq 40$ $\mathrm{mm}, w / 2 h \geqq 3$ でる.ここで式( 3 ) 〜 (6)の $z^{\prime}$ と $2 h$ は mmで表したときの数值であるが, 式 ( 2 )の積 分平均の際 $x$ 方向には単位長さ $(1 \mathrm{~mm})$ を考えている ので, 実質的には無次元数と考えることができる.図 からわかるように，板厚の増加とともに熱伝達は著し

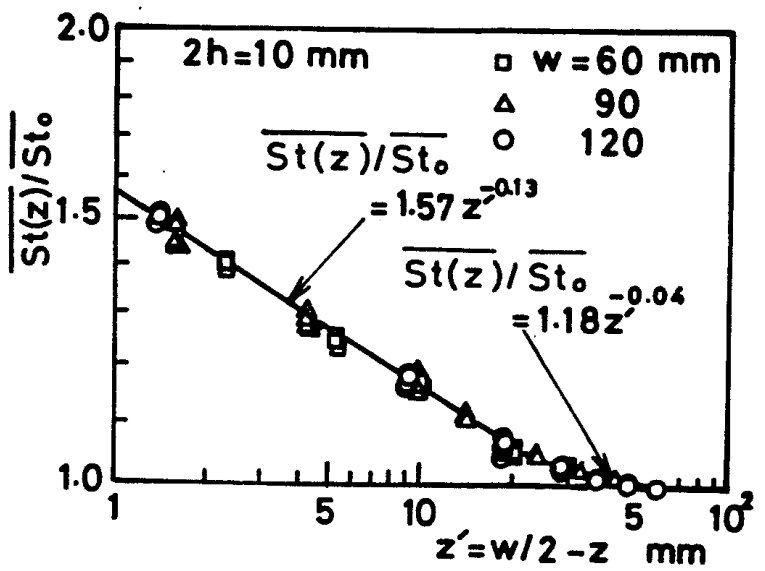

図 8 板厚による板幅方向の局所スタントン数の整理 
く向上し，しかも側端効果による $10 \%$ 以上の伝熱促 進の領域は, $2 h=10,15,20,30,40 \mathrm{~mm}$ に対し各々 $z^{\prime}$ $=15,21,25,27,30 \mathrm{~mm}$ と板厚に対応して板幅中心部 へ広がっている，また本実験では $2 h<10 \mathrm{~mm}$ の実験 値はないが，上式より薄板平板（とくに $2 h \leqq 5 \mathrm{~mm}$ )で は側端効果による伝熱促進は実質上期待できないもの と思われる。

なお実験式 $(3)$ ，（4)の基準スタントン数 $\overline{S_{t_{0}}}$ を本 実験では各板厚に対して $w=120 \mathrm{~mm}$ 平板の $z=0$ $\mathrm{mm} に$ におる值をとったが, 実験自体の測定精度・再 現性・熱損失などの誤差をすべて考慮したとき， $\overline{S_{t_{0}}}$ を無限幅平板に対するスタントン数をとっても $10 \%$ の精度内で本実験式 $(3) \sim(6)$ は成立し, 伝熱促進量 を過大評価する恐れもないものと考えられる。

$3 \cdot 7$ 平均熟伝達事の実験式有限幅平板全体の 熱伝達率は実用上有用であるので, $\overline{S_{t}(z)} / \overline{S_{t_{0}}}$ を板

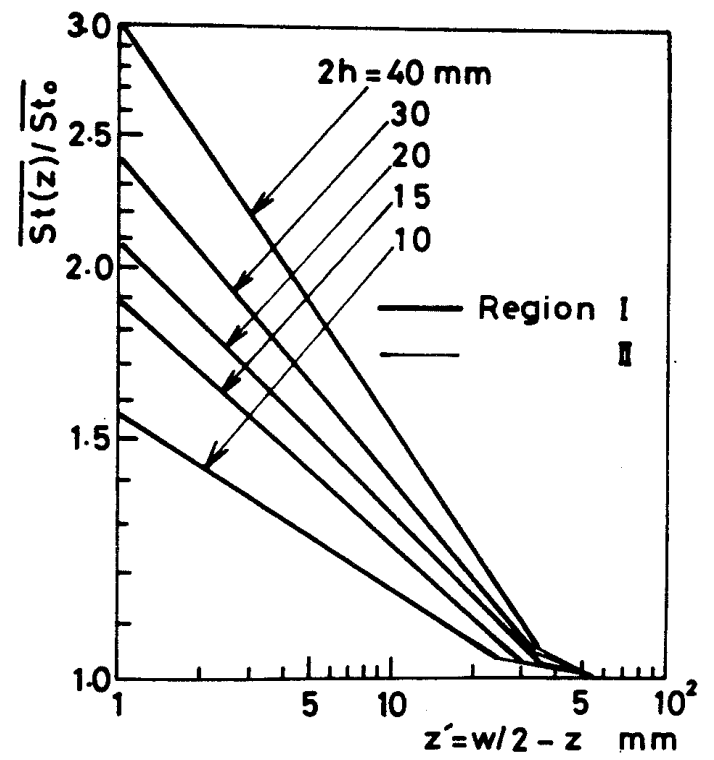

図 9 全板栗に対する板幅方向の統一的局所スタン トン数の整理

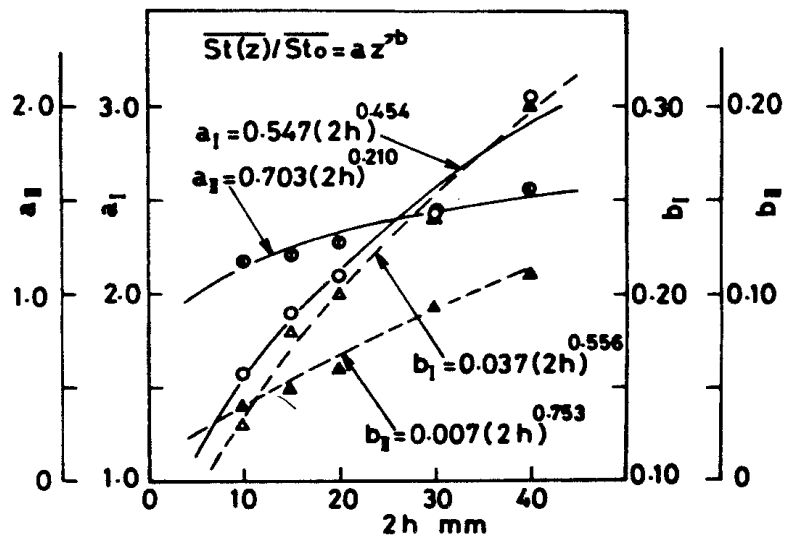

図 10 実験式 (3)と（4)に用いる係数 $a, b$ の近似式
幅にわたってさらに積分平均したスタントン数 $\overline{\left(\overline{S_{t}(z)} / \overline{\left.S_{t_{0}}\right)}\right.}$ を求め, 板幅 $w$ の関数として図示する と図 11 となる. 平均熱伝達率も 3.6 節と同様, 領域 I とIIに区分され，領域Iではかなり向上している。こ れより比較的板幅が小さく，板厚の大きい平板が実用 上有利となる。なお本実験式の適用範㬰は図に示す範 囲内である。この場合も板厚をパラメータとすれば， 各板厚に対して直線 I，IIで整理することができるの で,

領域 I：

$\overline{\left(\overline{S_{t}(z)} / \overline{S_{t_{0}}}\right)}=a_{\mathrm{s}} w^{-B_{1}}$

領域 II :

$$
\overline{\left(\overline{S_{t}(z)} / \overline{\left.S_{t_{0}}\right)}\right.}=\alpha_{\mathrm{II}} w^{-\beta_{\mathrm{II}}}
$$

なる形で表せば，各係数は図 12 で表される。

$$
\left.\begin{array}{l}
\alpha_{\mathrm{I}}=0.837 \ln (2 h)-0.384 \\
\beta_{\mathrm{I}}=0.064 \ln (2 h)-0.069 \\
\alpha_{\mathrm{II}}=0.169 \ln (2 h)+0.697 \\
\beta_{\mathrm{I}}=0.019 \ln (2 h)-0.033
\end{array}\right\}
$$

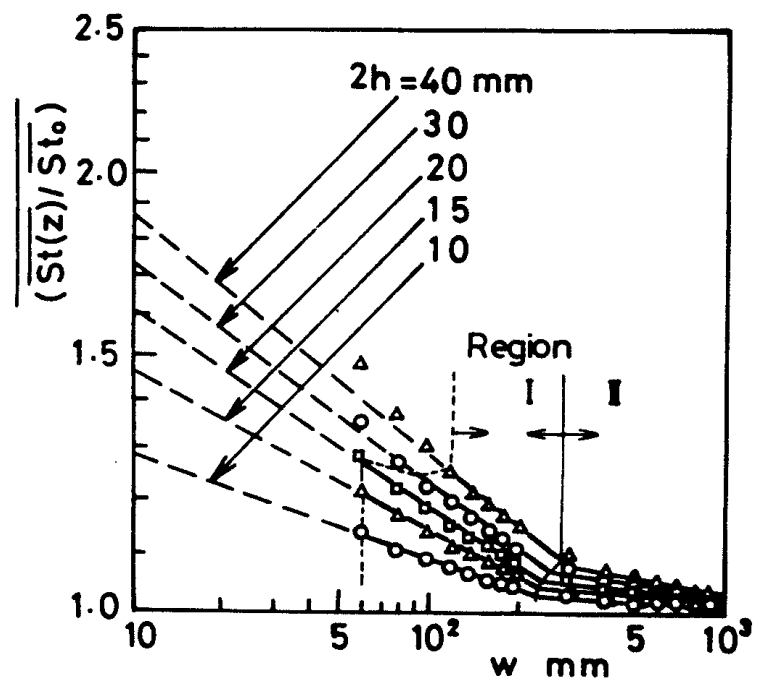

図 11 全板厚に対する板幅全体での平均スタントン数

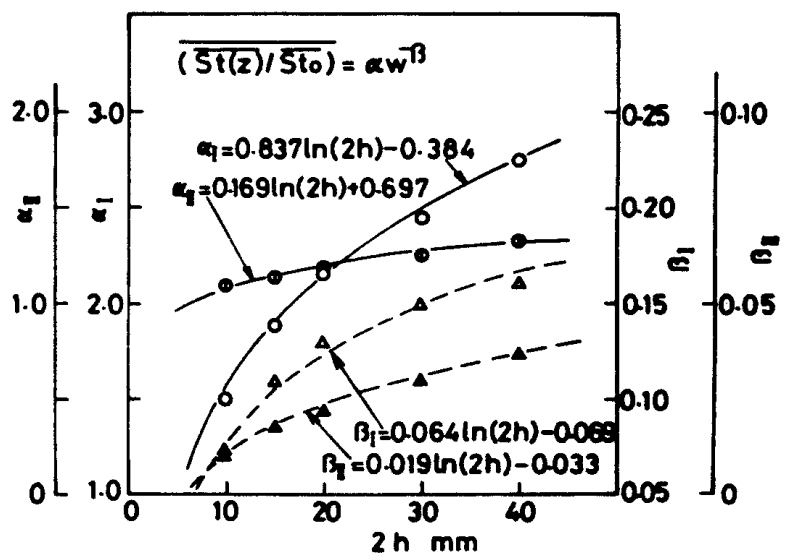

図 12 実験式 (7) と (8)に用いる係数 $\alpha, \beta$ の近似式 
ただし、適用範囲は， $w \geqq 60 \mathrm{~mm}, 10 \mathrm{~mm} \leqq 2 h \leqq 40$ $\mathrm{mm}, w / 2 h \geqq 3$ である. 側端効果による $10 \%$ 以上の伝 熱促進が期待できる板幅は $2 h=10,15,20,30,40 \mathrm{~mm}$ に対してそれぞれ $w<92,144,186,214,260 \mathrm{~mm}$ とな り，板厚とともに増加する．なお基準レイノルズ数 $\overline{S_{t_{0}}}$ については 3.6 節と同様に, 無限幅平板のスタン トン数を選んでも約 $10 \%$ 精度内で本実験式は成立 し，伝熱促進量を過大評価することもないものと考え られる。

\section{4. 結 論}

有限幅平板の側端付近に生ずる二次流れによる側端 効果が伝熱特性に及ぼす影響を明らかにするため，平 板上の乱流境界層に等熱流束加熱面を設置して，その 伝熱特性を種々の板幅と板厚に対して実験的に調べ， 主に無限幅平板と比較しながら検討した結果，以下の 諸点が明らかになった。

（1）有限幅平板の側端部に生ずる二次流れによ り，伝熱がかなり促進される。

（2）側端効果による伝熱促進の領域は板幅よりも 板厚の影響を強く受け，その領域は板厚が増加するに したがって側端から板幅中心部へ広がる。

（3）側端効果による伝熱促進量は板厚だけで評価 でき，板厚をパラメータとすればスタントン数を用い
ることによって，熱卮達率を系統的に整理することが できる。

（4）有限幅平板における板幅方向の局所熱伝達率 と板幅全体の平均熱伝達率はそれぞれ式 (3)〜 (6)お

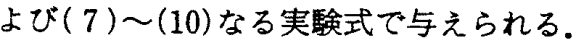

（5）本実験範囲内では，トリッピングワイヤ設置 の有無、熱流束 $\dot{q}$ おび流速 $U_{\infty}$ による有限幅平板 の熱伝達特性への影響はみられない。

（6）有限幅平板の熱伝達特性は，流動特性を調べ た前報 ${ }^{(6)}$ の結果とよく一致する。

\section{文献}

(1) Elder, J. W., J. Fiuid Mech, 9 (1960), 133.

（2）古屋・ほか 3名，機諯，41-350（昭 50）, 2878.

（3）古屋・ほか 3名，機論, 42-359（昭 51)，2091.

（4）中村・ほか 3 名，機論, 46-402，B (昭 55)，239.

(5) Carnavos, T. C. (Afgan, N. H. and Schlünder, E. U. 編) Heat Exchangers: Design and Theory Sourcebook, (1974), 441, Scripta.

（6）鳴海・ほか 4 名，機械前刷（第 922 回），(昭 58.7).

(7) Kato, S., ほか 2 名, Res. Rep. Fac. Eng. Mie Univ, 3 (1978), 37.

(8) Narumi, A., ほか 2 名, Res. Rep. Fac. Eng. Mie Univ., 7 (1982), 67.

( 9 ) Colburn, A. P.. Trans. Am. Inst. Chem. Eng., 29 (1933), 174.

（10）甲藤，伝熱概論，(昭 51)，117，意賢堂.

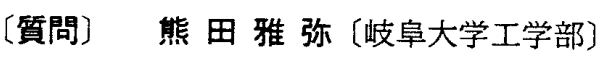

（1）乱流境界層の原点は，板厚および $U_{\infty} に$ 関係 なく,また $T . W$. がある場合でも, 前縁コーナ部 $(x$ =0）としてよいとする判断は，どのような理由からな されたか.

（2）前縁非加熱部の影響は，どのように補正され たか.

（3）実験式の適用範囲にアスペクト比の条件がつ いているが, 図 7 の結果は,アスペクト比一定に対し て, $\overline{S_{t}(z)} / \overline{S_{t w=0}}$ は $z^{\prime}$ に対して相似でない.このアス ペクト比は，現象を理解するうえでどのような物理的 意味をもつ無次元量か, ご教示願いたい.

（4） $x$ が実験式には陽的に含まれていないが, $\overline{S_{t_{0}}}$ の算出には必要である. $x$ (あるいは $R_{e x}$ )には条 件はいらないか. 特に $w / 2 h=3$ 程度で, 境界層厚さが $w$ あるいは $2 h$ と同程度以上になっても必要ないの か.

〔回答〕（1）本実験でも，ご指摘のような各場
合に対して乱流境界層の原点を求めたが，流れ場が前 粶はく離, 再付着, 再発達を伴い, しかも側端部の影 響を受ける場合もあり，統一的に精度よく決定するこ とが困難であった。また，種々の前縁形状の熱伝達へ の影響を調べた太田らの研究(付 1)でも，前縁コ一ナか らの距離 $x$ を用いた $N_{u x}-R_{e x}$ 曲線上での差異は小さ くColburnの式に一致している.さらに $x>110 \mathrm{~mm}$ の板幅中心を基準とした本実験の整理法の場合には， 原点の影響はほとんどないものと考えられる。

（2）非加熱部の補正は Spalding 関数および Reynoldsら(付2)の提案式によって検討したが， $x$ を 質問（ 1 ）のように取れば加熱部直後の測定点 $x=160$, $210 \mathrm{~mm}$ で若干その影響がみられるもののそれ以後は

(付 1) Ota, T. and Kon, N., Int. J. Heat Mass Transfer, 22 (1979), 197.

(付 2 ) Reynolds, W. C., ほか 2 名, NASA Memo., 12-2-58W (1958).

(付 3 ) Antonia, R. A., ほか 2 名, J. Fluid Mech., 80 (1977), 153. 
従来の二つの基準式内にあってほとんどその影響はみ られなかった. $1830 \mathrm{~mm}$ の非加熱部のある Antonia ら(付3)の結果でも加熱開始後 $250 \mathrm{~mm}$ ですでにColburnの式と一致し，その影響はかなり小さいこと，ま た本実験では側端効果による伝熱促進量に関心がある こと，などを考えて，本実験ではあえてご指摘の補正 をしないことにした。

（3）側端効果は，本実験範囲内の比較的大きなア スペクト比の場合，その影響をほとんど受けず，むし ろ板厚によって大きな影響を受ける。ここでのアスぺ
クト比は板幅中心部に平板流れが残っている有限幅平 ・板という意味の平板形状を示すのに用いた。本実験範 井外のアスペクト比については現在検討中である。

(4) ご指摘のように $\overline{S_{t}}$ の算出には $x$ が入ってく るが, 本実験のように $h(x, z) / n_{w=\infty}$ の $x$ 方向への変 化が非常に小さいという条件が満足されれば， $x$ に対 する制限はいらないものと考えている。しかし，三次 元性の強い流れ場で前述の条件が満たされない場合に は $x$ を含むパラメータの導入も必要であろう. 